\title{
THE SIGNIFICANCE OF GOD'S IMAGE IN MAN
}

\author{
Gerald Bray \\ Introduction
}

It is now nearly a quarter of a century since David Clines gave his 1967 Tyndale Old Testament lecture 'The image of God in Man'. ${ }^{1}$ Since that time, the flood of articles and books dealing with the image and likeness of God in man has multiplied a good deal, and the theological climate has changed considerably. ${ }^{2}$ Whereas Clines' radical repudiation of theological tradition went hand in hand with a most generous readiness to accept Ancient Near Eastern influences of all kinds, scholars now tend to insist that the question of the image must be addressed in theological terms, even though most of them continue to be unhappy with the way in which the classical tradition actually developed. ${ }^{3}$

This article outlines (i) the current state of exegesis; (ii) the problems connected with the traditional theological interpretation of Genesis 1:26; (iii) the newly recognised importance of intertestamental Judaism for a Christian doctrine of the image of God; (iv) an extended commentary on the relevant New Testament passages; and (v) a new theological reconstruction of the doctrine based on the evidence which the New Testament provides.

\footnotetext{
${ }^{1}$ In TynB 19, (1968) 53-103.

${ }^{2}$ See G.A. Jónsson, The Image of God. Gen. 1:26-28 in a Century of Old Testament Research, (Stockholm, 1988). In addition to the works listed there, see also J. Scharbert, 'Der Mensch als Ebenbild Gottes in der neuen Auslegung von Gn 1:26' in Weisheit Gottes - Weisheit der Welt I, St. Ottilien, 1987 (Festschrift for Josef Cardinal Ratzinger); J. Calleja, 'Gn 1:26s in Filone, nelle Omilie di Origene e nel Commentario in Genesim di Didimo il Cieco' in Melita Theologica 39 (1988) 91-102; R. Krawczyk, 'Starotestamentowa Idea Obrazu Bożego w Czsłowieku' in Rocznik Teol-Kanoniczne 31 (1984) 19-30.

${ }^{3}$ K. Barth, Church Dogmatics III, 1. (Edinburgh 1958) 195 sums up the feeling of many when he writes: 'Is it not astonishing that again and again expositors have ignored the definitive explanation given by the text itself, and instead of reflecting on it pursued all kinds of arbitrarily invented interpretations of the imago Dei?'
} 


\section{The Current State of Exegesis}

The semantic range of the main terms, tselem and $d^{\prime} m u$ th is now broadly agreed. The former refers primarily to a concrete image, a definite shape; the latter is more abstract-a resemblance, or a likeness. ${ }^{4}$ The big question raised by comparative usage elsewhere is whether tselem can ever be held to have a metaphorical sense. Everyone agrees that the Genesis accounts refer to man being made in the image of an invisible God, and that the thrust of the passage precludes worship of the human being as God's representative on earth. What is not clear is whether man is the tselem of God in body as well as in 'soul' (or however one is going to describe the nonphysical part of the human constitution), or whether tselem has any link to Israelite prohibitions against idolatry.

The high-water mark of the belief that tselem must always imply a physical image is generally said to have been the influential article written in 1940 by P. Humbert. ${ }^{5}$ For a time this view dominated Old Testament scholarship, and it was endorsed, with some minor reservations, by Clines. ${ }^{6}$ However, even in 1967 the tide was receding, and he also records some strong denials of Humbert's position. 7 Today those denials sound more convincing, especially since the frequent metaphorical use of tselem and its Akkadian cognate tsalmu, which Clines also recognises, ${ }^{8}$ has become more widely appreciated. ${ }^{9}$

It must now be concluded that tselem does not by itself imply that the human body bears some resemblance to God (still less that God has a body like man's), and therefore that the nature of the body's involvement in the concept of the image must be decided on other grounds. As far as prohibitions against idolatry are concerned, it must be said that there is no obvious link between Genesis 1:26 and Exodus 20:4, which is the

\footnotetext{
${ }^{4}$ See G. Wenham, Genesis 1-15, (Waco 1987) 29; C. Westermann, Genesis 1-11 (London 1984) 146.

${ }^{5} \mathrm{P}$. Humbert, Etudes sur le récit du paradis et de la chute dans la Genèse, (Neuchâtel 1940) 153-75.

${ }^{6}$ D. Clines, op. cit., 56-8.

7 Ibid., 59-61.

8Ibid., 74.

${ }^{9}$ See C. Westermann, op. cit., 150.
} 
passage most often cited in this connection. The vocabulary is different, and the Exodus passage does not give the creation of man in God's image as a reason for prohibiting idolatry, which one would certainly expect if the two passages were directly connected. We must therefore conclude that there is no exegetical evidence which compels us to believe that the Genesis passages were composed as part of a campaign against the worship of idols.

A related issue, and one which by its very nature is far harder to resolve satisfactorily, is the question of Egyptian and/or Babylonian influence on the composition of the Genesis texts. Tsalmu is found in Akkadian to refer to an image set up to commemorate royal authority and dominion, and it was long thought that this meaning must also lie behind Genesis. It is of course true that the idea of dominion is present in Genesis 1:26, but, as Westermann points out ${ }^{10}$, if this idea were borrowed from the royal ideology it would mean that every single human being was an image representing the rule of God. While this is not completely impossible, it hardly sits well with the concept of a Chosen People who were called to fulfil the Law of God in a special way and therefore it is most improbable that it could be the work of $P$. At most there may be faint echoes of a royal ideology which would strike the hearer as an enormous contrast to the Israelite conception of the image of God. That there was such a contrast is agreed by everyone; whether it was deliberately intended or not remains unknown, and probably unknowable. In any case, it is also generally agreed that the concept of dominion, however important in itself, is merely an attribute of the tselem and does not constitute part of its essence. ${ }^{11}$

A more awkward question is raised by the use of the plural in Genesis 1:26, implying as it does that man, as the image of God, somehow reflects a plurality in God. Here, there is no unanimity among interpreters. All are agreed that the Israelite God is One, and that the use of the plural here cannot imply polytheism. The suggestion that it may reflect an earlier, pre-Israelite polytheism, which was not edited out when the account was compiled, seems to be highly unlikely, if

${ }^{10} \mathrm{C}$. Westermann, op. cit., 153-4.

${ }^{11}$ Ibid., 153; see also G. Wenham, op. cit., 30-2. 
only because this is just the sort of thing a convinced monotheist would be on the look-out for. More probable is the idea that God is here speaking to the heavenly hosts, though this raises such questions as whether angels are also created in the image of God, whether angels took part in the work of man's creation, and even whether man is created in the image of angels. ${ }^{12}$ The further suggestion that this is a royal 'we' is now generally rejected on the ground that the Bible does not use the royal 'we' of God, though it is sometimes argued that the plural is a form of self-encouragement, rather as we might say, 'let's see, I wonder whether. . $\therefore 13$

The role of angels in the creation of man has been debated for a long time. That the Israelites were conscious of an ontological hierarchy is known from Psalm 8:5-6, where we are told that God created man a little lower than the angels, and gave him dominion over creation. This hierarchy is confirmed in Hebrews, where the Psalm is quoted (2:7) and it is important to recall that the writer felt obliged to discuss the question of Christ's relationship to angels at some length. His argument is that by becoming man, the Son of God, who is by nature far above any angel, elevated the elect, who have become His brothers by adoption, to a position higher than that of the angels, a status confirmed by Paul when he says that we shall judge them (1 Cor. 6:3).

But this judgment will presumably take place at the realisation of the eschaton. Meanwhile, the created hierarchy remains, and man must show deference to the angelic hosts (1 Cor. 11:10), though not to the point of obeying them if they should somehow interfere with the teaching of the Gospel (Gal. 1:8). The message seems to be that whilst we are lower than angels by virtue of our creation, our relationship to God is not dependent on them. As there is nothing in the Bible to suggest that we are created in their image, or that they participated in our creation, it is probably best to leave these questions out of the discussion altogether. On the other hand,

\footnotetext{
${ }^{12}$ On this, see Thomas Aquinas, Summa Theologiae, I, 93, 3. G. Wenham mentions the possibility, also favours the view that us $=$ angels who also have a divine image, op. cit.., 28.

${ }^{13} \mathrm{C}$. Westermann, op. cit., 145 , following a number of modern scholars.
} 
there are similarities between angels and men which cannot be overlooked, especially since they would appear to be shared by God as well, and these may provide some basis for deciding whether angels are also created in the image of God. ${ }^{14}$

To return to the problem of the plural in Genesis 1:26, the most likely answer is that God is speaking to other beings who share whatever it is $\mathrm{He}$ is about to give to man, but that the actual work of creation is His alone. ${ }^{15}$ This impression is reinforced by Genesis 3:22, where God says 'Behold, the man has now become like one of us', a use of the plural which clearly excludes any form of inflated singular. Who these other beings are is not stated in the text, leaving a great deal of room for speculation. Christians have often argued that the reference is to the Trinity, although there is no suggestion of this either, in spite of the plea made by Karl Barth. ${ }^{16}$ His argument for a plurality in God is not without some foundation, but the texts he uses to support it come, as indeed they must, from the New Testament, which speaks of Christ the Son as having taken part in the work of Creation (Jn. 1:3; Col. 1:15-16).

Colossians 1:15 offers the most convincing evidence for a Trinitarian interpretation, because Christ the Creator is there described as the eikôn tou Theou tou aoratou ('image of the invisible God'), but it should be noticed that although this passage is quite specific about the relationship of the Son of God to the Father, it does not say anything about the creation of man, either in the image of the Trinity or in the image of Christ. This question arises from a comparative study of Pauline texts, especially those which refer to Christ as a new Adam, but there is no evidence that the two concepts were directly linked in the Apostle's mind. ${ }^{17}$

Working from the text of Genesis 1 itself, Clines suggested that God might here be addressing His Spirit, which

${ }^{14}$ This idea is strongly criticised by Karl Barth, op. cit., 192. Speculation on these shared qualities has been endless, but ultimately fruitless, because of lack of evidence. See G. Wenham, op. cit., 30.

${ }^{15}$ The usual modern view. See G. Wenham, op. cit., 28.

${ }^{16} \mathrm{~K}$. Barth, op. cit., 191-206. For a brief but firm refutation of his arguments, see P.E. Hughes, The True Image: The Origin and Destiny of Man in Christ, (Leicester 1989) 18-21.

${ }^{17}$ See H. Ridderbos, Paul: an Outline of his Theology, (Grand Rapids 1975) 93100. 
would introduce a slightly different twist to the Trinitarian interpretation. He points out the role of the Spirit in creation (Gen. 1:2) and cites other Old Testament passages in which the idea of a Creator Spirit appears. But he does not press the point, it has not been taken up by other exegetes, and we must conclude that the text offers no evidence to support it.

In the LXX, tselem is regularly, though not always or exclusively, translated as eikôn. The Greek word conveyed the same idea of 'concrete image' and was doubtless therefore regarded as a suitable rendering for tselem. It should be borne in mind though, that eikôn was first widely used by Plato to refer not to an idol or a copy of some other reality, but to a thing which has a genuine share in the reality depicted, to the point where it may even be identified with that reality. According to Plato (Timaeus 30b), the world is created in the image of God, and man, or at least the human soul, is a replica of the world (ibid. 43a). But in his scheme, man is altogether inferior to the world, which is perfectly animate and rational, being a true eikôn of God, which man is not. The belief that man is a mikros kosmos, or as we would say, a microcosm of the image, is of a much later date and does not appear in Greek thought until after the influence of Philo and the Early Christians had introduced the Hebraic notion of man as the image of God. ${ }^{18}$ Thus we may safely assume that the translators of the LXX did not borrow Greek ideas when they used eikôn for tselem, but merely found the word most suitable for their purposes and adapted it as necessary.

The translation of $d^{\prime} m u t h$ is much less straightforward than that of tselem. In Genesis 1:26, the Greek word used is homoiossis, an unusual form which can also be traced back to Plato in the sense of 'likeness, resemblance'. But in Genesis 5:3, $d^{\prime} m u t h$ is translated as idea and in Genesis 9:6 as eikôn! Even if we allow that the last of these may have been a slip of the pen, it is obvious that $d^{\prime} m u$ th did not have anything like the same shape about it as did tselem. The Greek words used to translate it emphasise visual, and therefore essentially

${ }^{18}$ See J. Fantino, L'homme image de Dieu chez saint Irénée de Lyon, (Paris 1986) 7. Note that Gregory of Nyssa was deeply opposed to the concept of microcosm. Opif. Mun. 16. 
superficial, resemblance, adding weight to the consensus of Old Testament exegesis that the d'muth cannot be regarded as a distinct entity in its own right. This only confirms the persistence of the Hebraic concept into Hellenistic times, and makes the later development of homoiôsis into a thing paralleling eikôn all the more inexcusable.

\section{The Problems of Traditional Theology}

Old Testament scholars have long noted that the history of Christian exegesis had gone astray, particularly in the development of the concept of homoiôsis, and argued that it could therefore be disregarded. It was often remarked that both the phrase 'image (and likeness) of God', and clear allusions to it are so rare in the Old Testament as to make it questionable whether the concept had any real significance for Israel. ${ }^{19}$ According to this line of reasoning, the early Church, almost certainly under Hellenistic influence, moved far away from its Old Testament roots and developed an idea which had only the most slender basis in the original text. This might have been understandable in the days when 'proof-texting' was an acceptable method of doing theology, but it could hardly be sustained in the era of scientific Biblical study!

Nowadays it is more generally accepted that in deciding how important the concept of the image and likeness of God is (or was) in Old Testament theology, the greatest caution is required. The image of God in man does not occur often, but it comes at significant moments-the crowning of creation, the beginning of the genealogies and the prohibition of murder, which clearly distinguishes human from merely animal life. It also reappears in the New Testament, having been the object of considerable speculation during the intertestamental period. We might also add that the vast amount of attention paid to it both by Christian tradition and by modern scholarship (sometimes in the interests of demonstrating its insignificance!) shows that the concept cannot simply be dismissed as a matter of little or no real importance.

The theological question cannot be ignored, but how it

\footnotetext{
${ }^{19}$ See G.C. Berkhouwer, Man: the Image of God, (Grand Rapids 1952) 67; also V. Lossky, In the Image and Likeness of God, (London 1975) 125-32.
} 
should be posed remains a major divide between traditional and modern ways of thinking. The modern scholar, deeply rooted in exegesis, tends to look within that discipline for clues which will point him in the direction of a coherent theology. This would be a laudable endeavour were it not for the fact that the exegetical tradition is vitiated by certain weaknesses in method which make the whole enterprise questionable. The first of these weaknesses is the over-reliance placed on lexical study as the key to meaning. This has been amply demonstrated and criticised by Professor James Barr. ${ }^{20}$

A second problem with an exegetically-based theology is that exegesis is still very much in thrall to the Documentary Hypothesis of the Pentateuch, in spite of the many revisions which the latter has undergone since the days of Wellhausen. Because of this, we are asked to consider not the theology of Genesis but of $\mathrm{P}$, a shadowy figure whose precise date and purpose in writing (or compiling earlier sources) remains obscure. Unfortunately, everything depends on finding answers to these questions, and this can only be done by making certain assumptions about the meaning of the text. The result is a circular argument which depends for its validity on the belief that one hypothesis can reliably be built on another.

If we assume that there was a $P$, we must then assume that he had a particular theological outlook which is reflected in his documents. But deciding which documents are his depends on isolating a particular theological strand in the Pentateuch! If we agree that $P$ was a later author who was concerned to emphasise the uniqueness and importance of the Israelite cult, we will be inclined to take Genesis 1:26 and related verses as reinforcing prohibitions against idolatry. But as.we have already indicated, there is nothing in the actual texts which suggests this, and much which points in a very different direction. It is hard to believe that a monotheistic writer of the exilic period would have left the plural for God unaltered and unexplained; hard too, to believe that his main purpose was to demythologise pagan beliefs. Would a contem-

\footnotetext{
${ }^{20} \mathrm{~J}$. Barr, The Semantics of Biblical Language, (London 1961). For Barr on the image, see 'The Image of God in the Book of Genesis - a study of Terminology' in BJRL 51, (1968-9) 11-26.
} 
porary of Jeremiah really have been as subtle a denouncer of idolatry as this?

The Genesis texts are universalistic in scope, and not obviously interested in cultic matters; it is never suggested that man was created in God's image so as to be able to worship Him, for instance. ${ }^{21}$ The express statement that women as well as men are created in God's image hardly fits an all-male priesthood which discriminated against women, nor does it sit well with genealogies which mention only males. ${ }^{22}$ Even the dominion which man has been given over creation is hard to tie in with animal sacrifices, which were supposedly of enormous significance for $P$. After all, how could a mere animal be a substitute for a being created in the image and likeness of God?

Things are not made any easier by the fact that Genesis 1:26 appears to have closer links with the so-called J material in Genesis 3 than with the rest of P! It is symptomatic that both Karl Barth and Wolfhart Pannenberg have confused the two sources in their interpretation of the image, not because they are unaware of them but because it seemed to them to fit the overall argument best. ${ }^{23}$ But once the divide between J and $P$ breaks down, is there any point in trying to maintain that there is such a thing as a theology of $\mathrm{P}^{24}$

\section{The Importance of Intertestamental Judaism}

One of the most remarkable developments of modern times has been the renewed demonstration by scholars that the most fruitful period of theological speculation about the image of God in man was the so-called 'intertestamental period', a time which is of special importance to Christians because of its influence on the New Testament. It is a curious fact that almost all the ideas about the image which were later to be developed by the Christian Church appeared during this period, and are reflected in the speculations of the rabbis and others.

\footnotetext{
${ }^{21}$ An important point. See P.E. Hughes, op. cit., 55-6.

${ }^{22}$ An argument which Barth ignores in his defence of a male-female image. See also M. Hayter, The New Eve in Christ, (London 1987) 60-79, who argues that the role of women in the Israelite cult is unrelated to any concept of sexuality in God.

${ }^{23} \mathrm{~K}$. Barth, op. cit., 191; W. Pannenberg, Anthropology in Theological Perspective, (Edinburgh 1985) 54.

${ }^{24}$ C. Westermann, op. cit., 144-5.
} 
Intertestamental Judaism was the first to speculate about the use of the plural in Genesis $1: 26$, and it is there that we find the two most popular solutions already being propounded, viz. the idea that God was communing with Himself ${ }^{25}$ and the idea that $\mathrm{He}$ was speaking to angels. ${ }^{26}$ From this period too, come the first hints that the image was diminished after the Fall of man. The Old Testament never suggests anything of this kind, and modern scholars agree that Genesis 9:6 points to man's retention of the image after the Fall. ${ }^{27}$ It is true that at first the rabbis did not generally identify the loss or corruption of the image with the Fall itself; ${ }^{28}$ as far as they were concerned, Adam continued to be the full image of God until the day of his death. What happened, they maintained, was that after Adam's time, the image gradually diminished, not by the inheritance of Adam's guilt, but because of the sins of individual men. ${ }^{29}$ According to Abba Kohen, the divine image disappeared after the time of Enoch, ${ }^{30}$ and there is a legend that Rabbi Banaah was allowed to see the grave of Abraham because he was the likeness of the divine image, but not that of Adam, who was the divine image itself. ${ }^{31}$

The idea that the image implied dominion over the Creation was a popular theme, already found in Psalm 8, and repeated in Sirach 17:3. But to this traditional statement, Sirach adds that man was also able to distinguish between good and evil, thereby introducing a moral dimension into the concept of the image $(17: 6-10)$. This in turn leads to the

${ }^{25} \mathrm{G}$. Kittel, TDNT, 2, 392 quotes this as the opinion of Rabbi Ammi.

${ }^{26} \mathrm{Ibid}$., quoted as the opinion of Rabbi Acha.

${ }^{27} \mathrm{D}$. Clines, op. cit., 100 . The reluctance of dogmaticians to accept this is mentioned and discussed in A.A. Hoekema, Created in God's Image, (Grand Rapids 1986), 64-5. But see also W. Pannenberg, op. cit., 54-60 for examples of dogmaticians who accept this point and try to work it into their system.

${ }^{28} \mathrm{G}$. Kittel, op. cit., 393.

${ }^{29} \mathrm{Ibid}$.

${ }^{30}$ Gen. r. 23 on $4: 24$, cited by G. Kittel, ibid. Whether there is any Biblical justification for this view is something of a moot point. In modern times, Gerhard von Rad accepted it, claiming that 'the steady decline from the long lives of the earliest patriarchs has the theological implication of a degeneration of man's original powers and divinely given habitus'. (Ibid 392) This may be right, but if so, it is an inference from the context and not an explicit statement in the text.

${ }^{31}$ Cited by G. Kittel, ibid. 
statement that man is able to know God by keeping the Law (17:13), a view which was to become increasingly popular as Judaism evolved. ${ }^{32}$ The significance of this evolution is that the concept of the image subtly changes from being seen primarily as a relationship established between God and man and becomes instead a gift enabling man to achieve a closer union with God. ${ }^{33}$

The introduction of the moral issue had fateful consequences for the interpretation of the image, and these too, are still very much with us. In particular, the idea that the image was lost after the Fall became much more prominent than it had been before. Admittedly, there was a school of thought which insisted that the image cannot have been lost at the Fall, since if it had been, man would not now be able to keep the Law. ${ }^{34}$ But although this tendency never disappeared, it was gradually supplemented by the view that God's justice demanded punishment, and that as a consequence of this, the glory of God was withdrawn from man after the Fall. Only with the gift of the Law and the Covenant did it become possible for man to attain to the glory of God once more. ${ }^{35}$ Here it must be noted that the term preferred by the rabbis was glory (kabod; doxa) not image, and this too, is significant for future developments. Gradually the picture emerged of an image deprived of God's glory, a concept which Christians identified with His likeness, and the classical idea of a two-part image was born. ${ }^{36}$

It is with Philo that the influence of Greek ideas becomes apparent, and his impact on later Christian thought was enormous. For Philo, there were images of God in Heaven,

\footnotetext{
${ }^{32} \mathrm{~J}$. Fantino, op. cit., 11-13.

${ }^{33}$ It was to be this aspect which would prove so attractive to the Fathers of the Early Church, who would think of the image as the basis making it possible for man to attain to the divine likeness, and its appeal is not yet dead. Even Dr Clines, who officially eschews all reference to this kind of tradition, is able to conclude by saying that 'the image is fully realised only through obedience to Christ; this is how man, the image of God, who is already man, already the image of God, can become fully man, fully the image of God'.(op. cit. 103)

${ }^{34}$ J. Fantino, op. cit., 13; see also G. Kittel, op. cit., 394.

${ }^{35}$ Ibid., 15.

${ }^{36}$ P.E. Hughes, op. cit., 7-9.
} 
which he identified with Wisdom ${ }^{37}$ and Mind (nous). ${ }^{38}$ The human mind, though vastly inferior to the heavenly Nous, is nevertheless modelled on it, the Logos being regarded as the archetypos idea. The Logos is frequently referred to as the image of God, and the immortal soul is fashioned according to it. ${ }^{39}$ This view was to have an illustrious future, becoming the foundation of most Patristic and mediaeval thought on the subject. Its great weakness is that it tends to exalt human rationality to a place denied it in Scripture (cf. e.g. 1 Cor. 1:18-2:16). Today, however, even the strongest supporters of the classical tradition usually feel obliged to reject this aspect of it. ${ }^{40}$

Of utmost importance for Philo is the belief that man is the image of God at one remove, being created in the likeness of an archetype, which is not the world, as in Plato, but the Logos. Genesis 1:26 describes the creation of a 'heavenly man', who lacks any element of mortality or earthiness, and who therefore does not have a human body. ${ }^{41}$ The creation of the 'earthly man,' whose soul is also made according to the archetype, but who has a physical body which bears no resemblance to God, is described in Genesis 2:7.42 Philo's refusal to countenance the idea that the body could have been created in the image of God is often cited as a clear instance of Platonic influence on his thought, though it should be borne in mind that Judaism had long rejected crude anthropomorphism and would not have accepted the idea that God has a physical shape resembling that of a man. ${ }^{43}$ On the other hand, it did not make the kind of separation between body and soul which we find in Philo. For example, his contemporary, the great Rabbi Hillel taught that bathing was a way of caring for the divine image in man, thereby associating the image with the physical body. ${ }^{44}$ It is

${ }^{37}$ Leg. All. I, 43.

${ }^{38}$ Ibid., I, 33; 42.

${ }^{39}$ Ibid, I, 33. See also Plant, 18.

${ }^{40}$ See e.g. V. Lossky, op. cit., 138-9. Nevertheless, some defenders of this idea can still be found, e.g. E. Hill, Being Human, (London 1984) 196-215, and the notion that human rationality is part of the image of God is still widespread.

See e.g. P.E. Hughes, op.cit., 57-8.

41 Opif. Mun. 69.

${ }^{42}$ Leg. All. I, 31.

${ }^{43}$ See W. Eichrodt, Theology of the Old Testament, 2, (London 1965) 118.

${ }^{44}$ Lev. r. 34 on $25: 39$, cited by G. Kittel, op. cit., 393. 
interesting to note that in developing his idea, Philo was the first to come up with the hint that there were two creation accounts in Genesis, though of course he did not express this in the language of modern scholarship. He was also responsible for introducing the body/soul distinction into the discussion about the image of God, an idea which would be readily accepted by the Early Christians and which has been so strongly denied in modern times. ${ }^{45}$ Of more immediate significance to the Early Church was the identification of the Logos with the archetype according to which the image of God in man was created: it was this, and not the 'heavenly man' of Genesis 1:26 which the Church identified with Christ, in whose image man was then said to have been made.

When we look at these ideas in the light of the Old Testament, we are astonished at how little they have to do with the text. Nowhere in Genesis is there any suggestion that the image declined after the time of Adam, or that it had anything to do with keeping the Law. Nowhere is it stated that the image is either related to, or unconnected with, the physical form of the human body. Nowhere is it suggested that man was created after an archetype other than the Divine Being Himself, though Gordon Wenham has recently proposed a parallel text which might legitimate such a view..$^{46}$ It is all pure speculation, either totally unrelated to the text, or using it, as Philo did, in a curious and exegetically unacceptable way. Yet it was to be almost entirely from these ideas that traditional Christian teaching, including that of the Reformers, was to derive its content, if not its direct inspiration!

Most seriously of all, the idea that the image of God in man conferred moral awareness is directly contradicted by the narrative in Genesis itself. It is extraordinary that this was never recognized, yet it is plain for all to see that Adam, though he was created in the image of God, was not allowed to eat of the tree of the knowledge of good and evil. When he did so, God said 'Behold, the man has become like one of us', implying that in this particular at least, there had been an

${ }^{45}$ See C. Westermann, op. cit., 150; P.E. Hughes, op. cit., $10-14$.

${ }^{46}$ Exodus 25:9. See op. cit., 32. 
important dissimilarity between Himself and His human creature. What is more, God determined to put a stop to man's adventure by blocking the way to the tree of life, the fruit of which would have given him the other divine quality which he had previously lacked - immortality. Yet in spite of the obvious clarity of the Genesis narrative, generations of theologians have imagined that Adam in Eden was not only a moral being but immortal as well, and these two misconceptions continue to find their way into textbooks of Christian doctrine.

Oddly enough, had the rabbis recognised that the prelapsarian Adam did not possess moral awareness, they could have gone on to develop the idea that the image was originally designed to progress from glory to glory, as man got progressively nearer to God. Why was it that nobody seemed to notice that the 'Fall' was not a departure from the presence of God but a drawing nearer to Him? Man sinned because he succumbed to the temptation to be like God, and he was granted his wish. What is more, this gift was not revoked as part of man's punishment: nothing could be further from the truth than the suggestion that salvation consisted of being restored to the image of God as this had existed in the Garden of Eden. ${ }^{47}$ The whole thrust of the Biblical narrative leads away from the innocence of the Garden, so much so that when the tree of life reappears in the book of Revelation, it is sited in the midst of the City, that great sign of human rebellion against God. ${ }^{48}$

The key to the rabbis' failure, or unwillingness, to perceive these things must lie in the role which they assigned to the Law. It is hard to see how the Law could have been an instrument of salvation if man had no way of keeping it, and so some point of contact with the Divine standard of behaviour had to be preserved. The moral component which was subsequently read into the image became a necessity in this scheme of things, for without it the plan of salvation could not have been realised.

What is incomprehensible, and indeed tragic, is that

\footnotetext{
${ }^{47}$ This idea is contradicted by Paul's teaching about the second man, the last Adam, in 1 Corinthians 15:45-9. But it has a way of resurfacing in phrases like 'the restoration of the shattered image', which makes it possible for man to embark on a renewed search for God. See e.g. E. Hill, op. cit., 214-5.

${ }^{48}$ See J. Ellul, The Meaning of the City, (Grand Rapids 1970).
} 
the Christian Church was unable to see that once salvation by the Law was rejected, the moral character of the image had no more role to play. By preserving the concept of a morally responsible image, the Fathers of the Early Church opened the way for every shade of what would later be known, and condemned, as 'Pelagianism'. ${ }^{49}$ Even the Reformers, failed to perceive that the image of God in man was not supplied with moral awareness, with the result that they were obliged to say that it had been more or less completely lost at the Fall. ${ }^{50}$ This non-Biblical doctrine became necessary, not because they had a false view of the effects of sin, but because they failed to understand what Adam was like before he succumbed to temptation. The first error made the second inevitable, and it has coloured theological study ever since. ${ }^{51}$

\section{Theological Reconstruction: the New Testament}

There is no doubt that when we turn from the world of Philo and the rabbis to the pages of the New Testament, we enter a far more sober and less speculative atmosphere. In the context of the time, the New Testament stands out as a model of sobriety and reticence, especially when it is compared to the Hermetic or Gnostic speculation with which it had to compete in the early centuries of the Church.52 Direct references in the New Testament to the image of God in man are few. The word eikôn occurs 23 times and homoiôsis once, but of these occurrences the 10 in Revelation and the one in Hebrews are irrelevant to our concerns.

The threefold occurrence of eikôn in the famous Synoptic parallel in which Jesus replies to the Pharisees' question about paying taxes to Caesar (Mt. 22:20; Mk. 12:16; Lk. 20:24) may have some bearing on the matter, in that Jesus may be implying that whilst the coin bears the image of Caesar, men bear the image of God and so ought to give themselves to Him. ${ }^{53}$ We know from other parts of the New Testament that this would be compatible with Jesus' teaching in general, and

\footnotetext{
${ }^{49}$ See e.g. G.C. Berkhouwer, op. cit., 163-9.

${ }^{50}$ So Berkhouwer, ibid., 119-47.

${ }^{51}$ See A.A. Hoekema, op, cit., 66-101, who sees the problem but cannot escape it.

52J. Fantino, op. cit., 21-2.

${ }^{53}$ G. Bornkamm, Jesus of Nazareth, (London 1966).
} 
the suggestion that that is what is meant here is an attractive one. But as I.H. Marshall says: 'this. . .is more of a (correct) theological deduction from the saying than an inherent element in the argument, the comparison being more between Caesar and God than between coins and men'. ${ }^{54}$ We cannot therefore use it as part of our argument for developing a doctrine of the image of God in man.

This leaves us with the nine occurrences of eikôn in the Pauline Corpus, and the one occurrence of homoiôsis in James 3:9. This last is fairly straightforward and can be dealt with quickly. In James 3:9 we are condemned for using our tongues to curse men, who were made according to God's likeness. This is usually taken as a reference to Genesis 1:26, and ultimately that is obviously the case. However, despite the fact that James uses homoiôsis (the only occurrence of this word in the New Testament), it seems better to relate the verse in the first instance to Genesis 9:6, i.e. to the prohibition against shedding blood. To curse a man is to kill him spiritually in our heart, and it seems probable that James is here alluding to this aspect of Jesus' teaching (cf. Matthew 5:21-2). 55

It is when we turn to the use of eikôn in Paul that both the most obvious sources and the most intractable problems for a New Testament doctrine of the image of God in man appear. Of the nine occurrences of this word, not one can be completely ruled out as irrelevant to our discussion. The one which comes closest to this is Romans 1:23, where sinful man is said to have exchanged the glory of the immortal God for the likeness (homoiôma) of the image of mortal man. There may be an underlying pun on Genesis 1:26, but as 'man' is immediately followed by 'birds, animals and reptiles' it seems more likely that eikôn is meant to mean the human shape reproduced in idols and not the image of God in man.

54I.H. Marshall, Luke, (Exeter 1978) 736.

${ }^{55}$ From our present point of view, it is important to note only that, according to James, the likeness has not been lost. Normally one would suppose that fallen man was an appropriate object of cursing, especially as the divine curse was Adam's punishment in Genesis 3:14-19. But James does not draw this conclusion, perhaps because he understood that it was not Adam, but only the serpent and the ground which were put under the curse. Man remains the likeness of God, and for that reason must not be slandered by the misuse of the human tongue. 
Of the eight remaining occurrences of eikôn, three are followed immediately by (tou) Theou and therefore clearly refer to the image of God, though whether this is the same sense as that intended in Genesis 1:26 is less clear. A direct reference to Genesis is certain only in 1 Corinthians 11:7, where Paul explains that the man, here understood in the narrower sense of male, is 'the image and glory of God', whereas the woman is 'the glory of the man'. This passage is important for a distinction it makes between male and female, which is not apparent in Genesis 1:26-7. Whether this means that it is not implied in Genesis 1:26-7, so that we could then say that Paul is here revealing a male chauvinist prejudice, is, of course, quite another matter. We shall have to return to this question in due course, but for the moment, let us note that the Apostle does not say that the woman is the image of the man, but confines his statement of subordination to the idea of 'glory'. This is a concept not found in the Genesis passage, but as we shall see, it is of great importance in determining what Paul's doctrine of the image of God in man was.

The other two passages which refer to the image of God do so with direct reference to Christ. They are 2 Corinthians 4:4 and Colossians 1:15. In both cases, the same phrase is used: hos estin eikôn tou Theou ('who is the image of God') with aoratou (invisible) added to this in Colossians. The two passages resemble each other further, in that this expression comes immediately after a reference to Christ's saving work. In 2 Corinthians, Paul speaks of 'the illumination of the Gospel of the glory of Christ', and in Colossians of 'the redemption and forgiveness of sins' which we have in Him. It therefore seems most probable that the phrase 'image of God' is meant to be understood in terms of the divine presence and power which was able to effect salvation in Christ. ${ }^{56}$

The implication common to both texts is that Christ was able to accomplish something which no other man or other being could, so that 'image of God' becomes a phrase which sets Christ apart from us, not one which unites Him to us in Adam. We ought therefore to interpret it as a statement about Christ's equality with the Father, and not about his identity with us.

${ }^{56}$ The position of most commentators, but curiously overlooked by Kittel. 
The Colossians passage goes on to describe Christ's work in creation, and it becomes immediately apparent that his 'image of God' is radically different from Adam's. Adam as the image is a creature, but Christ is uncreated. Furthermore, $\mathrm{He}$ is the author of the whole of creation, both visible and invisible. The evidence therefore suggests that neither of these passages refers to the image of God in man as understood by Genesis 1:267. Nevertheless, this conclusion has often been resisted. The objections that have been raised must be looked at more closely.

First, there is the claim that Christ is described as being the eikôn tou Theou, whereas in Genesis man is described as having been created kat' eikona. ${ }^{57}$ The presence of kata is held to imply that Christ is the archetype of which man is a copy, and that because of this, it is correct to connect these verses to the Genesis story. This sounds plausible at first sight, but we must remember that Paul also refers to man as being the image of God without using kata (1 Cor. 11:7), so this argument is a weak one. However, it does not stop Gerhard Kittel from saying that Paul 'equates Christ with the Adam intended in Genesis 1:27. This is confirmed in 1 Corinthians 15:45ff., where he speaks of Christ as the second Adam. This follows the lines of Philo's connecting of Genesis 1:27 with the heavenly man, this man being Christ for Paul and the Logos for Philo'.$^{58}$ Kittel says nothing about kata, but relies on Paul's teaching about the second Adam and Philo's doctrine of the Logos as evidence that Christ is the archetype of the human image of God.

As far as Philo is concerned, we have already seen that Kittel's linking of the Logos to the heavenly man is too simple. The heavenly man is not the Logos, but the man created in Genesis 1:26. Adam, the man of earth, was created in Genesis 2:7, and must be distinguished from the heavenly archetype. But Paul knows nothing of this distinction, and does not regard the eikôn tou Theou as applied to Christ as a creature, even an invisible one. This equation must therefore be rejected.

When we turn to the question of the second Adam, we are on far more difficult and controversial ground. There is no

${ }^{57}$ Thomas Aquinas, op. cit., I, 93, 5; mentioned by C.B. Cranfield, Romans 1. (Edinburgh 1975) 432.

${ }^{58}$ Op. cit., 396. 
doubt that the parallel and contrast between Adam and Christ is a fundamental theme of Pauline theology, but there is nothing to suggest that Adam is a copy of the heavenly Son of God. If anything, it is the other way found. Christ has come in the likeness (homoioma) of sinful flesh, in order to redeem mankind from the effects of Adam's sin (Rom. 8:3). In 1 Corinthians $15: 45-6$, we are specifically told that this order is intended by God. The first Adam is described as 'psychic' or 'animal' because he was a living soul (Gen. 2:7), but the second Adam is 'pneumatic' or 'spiritual', being Himself a life-giving spirit (pneuma zôiopoioun). The question of an image is not raised until v. 49, where it is applied to us, the believers. We who have borne the image of the earthy, will also bear the image of the heavenly, but as the context makes clear, this will not happen until the general resurrection at the eschaton.

In this connection it is significant that Paul refers to Christ both as 'the second man from heaven', an expression which must be carefully distinguished from 'the heavenly man', 59 and as 'the last (eschatos) Adam'. But Christ is not the spiritual man from heaven either by virtue of his pre-existent divine status, or as a result of His incarnation, both of which could easily be linked with the eikon tou Theou. On the contrary, it is the resurrection which gives these titles their meaning, so that the double occurrence of eikôn in v. 49 has nothing to do with the image of God in man as understood by Genesis. Christ who from all eternity was the eikôn tou Theou created the world, and then at a particular moment, He entered His creation as an eikôn tou choikou, which is just another way of saying that He became a man like us. Then, by rising from the dead, He became an eikôn tou epouraniou, the firstborn of many brethren.

This explains why Paul says in Romans 8:29, that God has predestined the elect to be conformed to the image of His Son, i.e. we have been called to share in the glory of Christ's saving work. The sharp contrast between the new man in Christ and the old Adam is brought into relief in Colossians 3:9-10-'. . having put off the old man with his deeds, and put on the new man, renewed in knowledge according to the image of the one

${ }^{59}$ See H. Ridderbos, op. cit., 84, n. 133. 
who created him. . $\therefore$ Of all the Pauline passages, this one is perhaps the most ambiguous. The phrase kat' eikona tou ktisantos auton so obviously reflects Genesis 1:26, that commentators have invariably remarked on the relationship. But in modern times at least, they have also agreed that the verse does not speak of a return to the prelapsarian Adamic state, which would go against what Paul says elsewhere about the contrast between Adam and Christ. They correctly point out that the phrase is conditioned by the 'new man', who is a 'new creation' in Christ (2 Cor. 5:17), so that the parallel with Genesis 1:26 is one which is also in stark contrast to it. ${ }^{60}$

We may therefore conclude that Paul's use of eikôn tou Theou with reference to Christ is designed to emphasize His oneness with God, not His oneness with us. There is, however, one last line of defence which can be used by the supporters of the idea that we have here a link with Genesis 1:26-7. Briefly, this is the claim that 1 Corinthians 15, when talking about Adam and Christ, says relatively little about sin, but puts its emphasis on the problem of mortality, which is resolved by the resurrection. It is true that Christ died for our sins (v. 3), but the power of sin is the Law which came long after the Fall and brought sin to life in us (v. 56; cf. also Rom. 7:7-11). Now that Christ has risen from the dead, sin has no more control over us (v. 17) and therefore has ceased to be a power in our lives.

Man has therefore been set free from the effects of the sin which he incurred when Adam ate of the fruit of the tree of the knowledge of good and evil, and is now able to resume his progress towards the fulness of the image of God. If we take the Genesis account of the Fall literally, this means that man is now free to pursue eternal life, the tree which was barred to him in the Garden of Eden, but which has now been made available in and through the resurrection of Christ. Thus to be conformed to the image of the resurrected Son of God is in reality to perfect the image of God in man which was left in an incomplete state in the Genesis account of creation! In the Christian Church, it is the Eastern Orthodox tradition which has come closest to this way of thinking, but it has not been en-

${ }^{60}$ See P.T. ƠBrien, Colossians-Philemon, (Waco 1982) 191-2. 
tirely absent from the thought of some Western theologians. ${ }^{61}$

As with the rabbis, sin in the Eastern Orthodox tradition can only be the free act of the individual person, not the result of something inherited from Adam. It is true that man is weakened by mortality and therefore inclined towards sin, but the concept of total depravity and universal human guilt are absent from this way of thinking. The Orthodox do not follow the rabbinical teaching about the Law, but believe that it is possible, thanks to the image of God, for man to transcend himself and co-operate with God in the work of restoring mankind to the image as it was in Adam and as it is again in Christ. ${ }^{62}$

This view, which to a Western ear sounds highly Pelagian, is nevertheless quite defensible on its own premisses and something very like it is almost bound to prove attractive to anyone who rejects the usual Western, or Augustinian, understanding of sin and inherited guilt. If it is also admitted that the image was not lost at the Fall, those who are still wedded to the belief that the image is somehow connected with man's moral awareness (and hence his capacity for taking moral decisions), will quite logically find themselves driven into a position of this kind. ${ }^{63}$

We may admit that this view has a certain plausibility, but can we accept it as valid? Modern Orthodox theologians themselves have realised that they must reject many aspects of the traditional teaching of the Greek Fathers about the image and likeness of God in man, but they continue to cling to the notion that the human-predicament is one of mortality, not of inherited guilt. For them, the Adamic image of God continues to play a vital role in the Christian's deification, which is the object and purpose of salvation in Christ. ${ }^{64}$

The answer to this question depends not so much on what we think of the image as on what we think of sin and its relationship to mortality. The key verse here is Romans 5:12, which the Eastern Church has generally interpreted as saying that human sin is the result of the mortality which Adam

\footnotetext{
${ }^{61}$ Notably Emil Brunner. See G.C. Berkhouwer, op. cit., 51-2; A.A. Hoekema, op. cit., 52-8 and D. Cairns, The Image of God in Man, (London 1973) 152-69.

62 J. Meyendorff, op. cit., 140.

${ }^{63}$ Thus, for example, E. Hill, loc. cit., and W. Pannenberg, op. cit., 43-79.

${ }^{64}$ See P. Nellas, The Deification of Man, (New York 1987).
} 
incurred by his disobedience, not of any guilt which mankind might have inherited. Western theologians, for their part, are inclined to admit that Romans 5 does not state the concept of inherited guilt in so many words, but are less inclined to say that it is not implied by Paul's argument. ${ }^{65}$ They argue, for example, that the concept of inherited guilt does not depend on the interpretation of a single verse, but is built up from the combined evidence of many passages in the New Testament. ${ }^{66}$

Also, it is not clear that the Genesis account can be used to say that man incurred mortality as a penalty for disobedience. The text says that he was deprived of immortality, which suggests that Adam was created, like the animals, as a mortal being. If animal death is not the result of sin, it is hard to see why the death of the animal part of man should be seen in this way. ${ }^{67}$ It is much better to read the Genesis story as that of a mortal being who was protected from death as long as he was obedient to the commands of God: disobedience removed the protection, and Adam was allowed to complete the life cycle which was normal to his physical being. ${ }^{68}$

But most significantly of all, the New Testament, and especially Paul's Epistle to the Romans, is quite clear that human mortality is an evil which is the direct result of sin (Rom. 6:23), and every human being who dies does so because he is sinful. This is true even of Christ, who on the cross became sin for us ( 2 Cor. 5:21). His death was the death of a sinner, a place which He assumed on our behalf (cf. Gal. 2:20). If it were not so, there is every reason to believe that $\mathrm{He}$ would not have died, but would have been assumed directly into Heaven, like the righteous of the Old Testament. If this picture is accepted, then the view that mortality can be divorced from inherited guilt loses any claim to Scriptural support.

There is now only one Pauline passage left in which the word eikôn is used. This is 2 Corinthians 3:18, where Paul writes that we all, with unveiled face, tên doxan Kyriou katoptrizomenoi tên autên eikona metamorphoumetha apo

${ }^{65} \mathrm{H}$. Ridderbos, op. cit., 99.

${ }^{66} \mathrm{Ibid}$., 100-7; see also G.C. Berkhouwer, op. cit., 48-51.

${ }^{67}$ See P.E. Hughes, op. cit., 398-407.

${ }^{68}$ Whether he would have died in the normal sense remains uncertain. Perhaps he would have been translated, as Enoch was (Gn. 5:24; Heb. 11:5). 
doxês eis doxan, kathaper apo Kyriou pneumatos.

The first problem concerns the meaning of the participle katoptrizomenoi. Does the force of the Middle Voice give it the essentially active sense of 'behold', or the essentially passive one of 'reflect'? In the first instance, the verse would imply that man does not possess the glory of God, but only sees it as a distant goal to be attained with the aid of the Spirit. This meaning suits those who believe that the image of God was lost after the Fall, but as we have already seen, that view is untenable, especially in the light of 1 Corinthians 11:7, where Adamic man is described not only as the image but also as the glory of God.

However, the word doxan does not refer to the glory of God present in the created Adam but to the glory which the Christian has received in the light of Christ. That this is so is apparent first of all from the phrase 'with unveiled face'. Here in the preceding verses Paul refers to the veil which was on the face of Moses, which continues to obstruct the Jews and prevent them from seeing the glory of God. In deciding whether katoptrizomenoi means 'beholding' or 'reflecting', we have to decide whether the unveiled face applies to Moses or to the people. J. Héring claims that in the light of Christ 'every Christian has become a second Moses ${ }^{\prime 69}$ reflecting the glory of God. W.G. Kümmel's argument that such an interpretation would destroy the difference between Christians and Jews rests on the assumption that Paul was contrasting the children of the new covenant with the children of the old, for whom the veil of Moses still operates to prevent them from understanding. ${ }^{70}$

But it should be noticed that the veil which covers the Jews covers their heart, whereas Paul explicitly says that Christians have an unveiled face, thereby comparing them directly to Moses, and not to the Jews. There is also the important fact that the glory of God was understood by Paul as something in which Christians participate, because we all share in the glory of His resurrection body (Phil. 3:21; Col. 3:4). For all these reasons, the reading 'reflecting', should be preferred to

${ }^{69} \mathrm{~J}$. Héring, The Second Epistle of St. Paul to the Corinthians, (London 1967) 27, n. 21.

${ }^{70}$ W.G. Kümmel, The Theology of the New Testament, (London 1974) 222-3. 
'beholding'. ${ }^{71}$ Finally, there is the addition of Kyriou, 'of the Lord', which Paul intends as an allusion to the specific glory of Christ, not to the glory of God in general. What this glory is is revealed a few verses further on in 2 Corinthians $4: 4$. It is none other than the Gospel of salvation. It is because the Christian is saved, not because he is a man created in the likeness of Adam, that he bears the glory of the Lord in 2 Corinthians 3:18. For this reason, J. Jervell's view that this passage is a commentary on Genesis 1:26ff, must be rejected. ${ }^{72}$

The second question raised by this verse concerns the interpretation of the phrase tên autên eikona. At least since the time of Jerome, the meaning of these words has seemed clear enough - what the Apostle is saying is that we are being transformed into the image of Christ (in eandem imaginem transformamur). The snag with this interpretation, which has gone unnoticed by virtually all scholars, is that there is no preposition eis, even as a textual variant, to introduce the phrase, though that would be normal in such a case. ${ }^{73} E$ is is unconsciously supplied, as in Jerome, but the hapax mê legomenon is left unexplained. This may be correct, but it is also possible that the phrase, which must refer back to the doxan in the previous line, has another meaning altogether. In fact, if we accept 'reflecting' as the better translation of katoptrizomenoi, we are almost obliged to find another meaning for tên autên eikona, since it makes very little sense to say that we are being transformed into an image which we already reflect, unless, of course, we fall back on the unlikely interpretation that the reflection is understood to be less than perfect. ${ }^{74}$

It seems that it is not impossible that tên autên eikona should be read here as an accusative phrase recapitulating the earlier part of the sentence in preparation for what follows. In that case, the whole phrase would read: 'we all, with unveiled face, reflecting the glory of the Lord, as that same image, are being transformed from glory into glory, by the Lord Spirit'. The phrase 'from glory into glory' could then be understood as

\footnotetext{
${ }^{71}$ This is accepted by A.A. Hoekema, op. cit., 23-4, but it continues to be resisted by the majority of commentators.

72 J. Jervell, Imago Dei, (Göttingen 1960) 173-6.

${ }^{73}$ See examples in SI.

${ }^{74}$ As does A.A. Hoekema, op. cit.
} 
the glory of the Lord Christ, which is the gift of justification by faith, is now being transformed into the glory of the Lord Spirit, which is the sanctification of the believer. But whether this is the correct interpretation or not, it is clear from the passage that what changes is the doxa, not the eikôn, which remains a fixed reality whether it is understood as the goal of our striving or as the foundation on which we build.

This brings us finally to the question of the meaning of doxa. Scholars are agreed that it was used in the LXX and in later Judaism primarily to translate the Hebrew word kabod, ${ }^{75}$ which designated the presence and awesome majesty of God. There was a rabbinical tradition to the effect that man was given a part in God's kabod which he lost at the Fall ${ }^{76}$ and as time went on, the belief grew that it would be restored by the Messiah. ${ }^{77}$ Furthermore, it seems that the withdrawal of the kabod did not mean that God had completely deserted His creation, any more than God's abandonment of His chosen people meant that he completely rejected them. ${ }^{78}$ The kabod continued to be present in the Law of Moses, and it is remarkable that Paul was able to say that it was this very presence which made sin a living factor in human life (Rom. 7:7-12). By bringing together the different passages mentioned above, we are thus able to build up a picture of man, created in the kabod of God but rebelling against it (Rom. 1:23), restored in the kabod of Christ and transformed in the kabod of the Spirit.

That there is a close connection between eikôn and doxa is well known. We have already seen that Paul uses them both together of Adam (though not of Eve) in 1 Corinthians 11:7, and they occur side by side in Romans 1:23 and 2 Corinthians 4:4 as well as in 2 Corinthians 3:18. The assumption that they are synonymous, not only with each other, but also with other words like morphê, has become commonly accepted in New Testament scholarship in recent years. ${ }^{79}$ It was probably this

\footnotetext{
${ }^{75} \mathrm{G}$. Kittel, op. cit., 242.

${ }^{76} \mathrm{Ibid} .246$.

${ }^{77}$ Ibid. 246-7,

${ }^{78}$ This is nowhere explicitly stated, but Genesis 4:15 reminds us that God continued to care for man after his expulsion from Eden.

${ }^{79}$ See R.P. Martin, Carmen Christi, (Cambridge 1967) 99-133; P.E. Hughes, op. cit., 47-50.
} 
kabod/doxa which Irenaeus assimilated to the likeness (homoiossis) of the image of God in man, though it must be remembered that it also enabled him to regard the likeness as something distinct from the eikôn. ${ }^{80}$ For in spite of all the undoubted similarities between the eikon and the doxa of God, the two terms remained stubbornly different. Irenaeus was right to sense this: his mistake was to connect the meaning of doxa with the word homoiôsis, which cannot be distinguished effectively from eikôn.

To understand what the difference is, we must begin from the concept of a loss or withdrawal of the doxa. It is plain from the New Testament that the presence of God's doxa in man can fluctuate: if this were not possible, 2 Corinthians 3:18 would not make sense. It is also true that whereas it is quite natural to say that the eikôn can reflect the doxa, it makes no sense to say that the doxa reflects the eikôn. Given that there is no evidence of a change in the eikôn after the Fall of man, it seems that we must conclude that it is some permanent and unchanging resemblance to God in man, whereas the doxa comes and goes according to man's obedience to God's commands. In other words, the eikôn is something which man possesses whereas the doxa is something which man reflects in varying degrees, but which in essence belongs to God. It thus becomes clear how and why the rabbis were able to say that after the Fall, man the eikôn of God beheld His doxa only in the Law, and why the New Testament writers were able to shift the divine doxa from the Law to Christ (Jn. 1:14). For some of them, in fact, it would appear that the doxa in which the Christian could now participate was all that really mattered, since they make no mention of the eikôn at all. ${ }^{81}$

We are now left with two further questions relating to the doxa before we conclude our investigation. The first of these concerns the doxa of the created Adam, reflected in the doxa extended from Adam to Eve. ${ }^{82}$ This is not mentioned in the Old Testament, where Eve is said to have been created, like

\footnotetext{
${ }^{80}$ See P.E. Hughes, op. cit., 9.

${ }^{81}$ This is true of both John and the writer to the Hebrews. See J. Fantino, op. cit., 20-1.

${ }^{82}$ For some of the implications of this for feminism, see M. Hayter, op. cit., 83117.
} 
Adam, in the image of God and nothing is said about glory. This has led many scholars to conclude that 1 Corinthians 11:7 must simply be reflecting this and that although Paul calls Adam both the eikon and the doxa of God, he does not understand these as two distinct things. ${ }^{83}$ Unfortunately, this view cannot be sustained from the text, since the whole point of what Paul says is to distinguish the two kinds of doxa. If eikôn and doxa are synonymous, it would be necessary to say that Eve was created not in the image of God but in the image of man!

Paul of course does not say this, presumably because he understood that it would go against the teaching of Genesis 1:27. His emphasis is entirely on the doxa, where he perceives that men and women are different. A woman, it seems, is created in the image of God but reflects the glory of the male, not the glory of God directly. Her appearance and behaviour must reflect this difference, which is not tied, as her submission is, to the fact that Eve sinned first and tempted Adam. ${ }^{84}$ What is at stake here is the order of creation, which is an extension of the hierarchical principle established in heaven. ${ }^{85}$ The difference of glory does not however imply inequality between male and female, any more than the difference between the Son and the Father implies an inequality between them. The comparison is apt, because although the Son of God was constantly concerned that glory should be given to the Father, and looked to the Father for His own glorification (Jn 17:1), the statement that he was the eikon tou Theou underlines His essential equality with the Father as God. ${ }^{86}$ Within creation, therefore, doxa bears witness to order and hierarchy, but not to inequality or enforced submission.

The second question about doxa concerns the moral element which may or may not be present in it. J. Jervell insists that Paul virtually identifies doxa with dikaiosynê, and cites the list of sins in Romans 1:18-32 as proof that because loss of the doxa is inevitably a descent into immorality, moral rectitude must be inherent in the doxa which God bestowed on man

\footnotetext{
${ }^{83}$ So e.g. J. Jervell, op. cit., 180.

${ }^{84}$ See 1 Timothy 2:11-15, based on Genesis 3:16.

${ }^{85}$ Hence the reference to angels in 1 Corinthians 11:10.

${ }^{86} \mathrm{G}$. Kittel, op. cit., 395.
} 
at his creation. Here it would appear that there is a confusion of concepts. Certainly it is true that fallen man became an immoral creature, but that does not mean that his life before the Fall can be described as 'moral' in the same sense. As we have already remarked, the Fall itself was characterised by the attainment of moral awareness, so that it is hard to see how this concept can be applied to the prelapsarian Adam, whose blessedness is attributed to Adam's obedience, not to his consciously moral behaviour. The moral issue entered the picture only after the Fall, and became associated with the divine doxa in and through the Law. Thus it is because the Law has now been internalised by Christ that the doxa of God in the new man has a moral character, not because this was inherent in the glory bestowed on man at creation.

\section{Conclusion}

The image of God in man, understood as something implanted in Adam at his creation, is mentioned only twice in the New Testament, in 1 Corinthians 11:7 and James 3:9. Other passages allude to it, especially Colossians 3:10, but they do not deal directly with it. In particular, the use of the word eikôn, even in the form eikôn tou Theou, cannot be taken as referring to Genesis 1:27 as a matter of course; when this term is applied to Christ, it is used to distinguish Him from other men, not to unite Him to them.

The New Testament, like the Old Testament before it, says nothing about a loss, corruption or defacing of the creation image of God in man; on the contrary, both Paul and James use it as the basis for their particular teaching. It is probably significant that both New Testament passages deal with relationships between human beings - in Paul, between man and woman; in James simply between people in general. The notion that the eikôn tou Theou is the basis on which human relationships should be based, and the standard by which they should be conducted is the common element which provides us with the key to understanding what the image of God in man means.

Relationships are only possible between persons, and it is this elusive concept, the thing which defines man as a 'who', not as a 'what', which gives the image its meaning. The 
Christian understanding of the person is built out of many elements, of which the image of God in man is only one. To get the full picture, one would need to add such Biblical concepts as 'name', 'heart', 'soul', 'spirit', 'face' (prosôpon; Latin: persona), which eventually gave us the term 'person', 'form' (morphê) and even 'substance' (hypostasis). Each of these made its contribution to the development of the Christian concept of the Person, and eikôn must not be privileged in a way which would distort the overall context of Scripture. The dangers to which this can lead are evident from the attempts which have been made to include the human body in the image, largely on the ground that the body is essential to the person. ${ }^{87}$

Equally misguided is Karl Barth's claim that the image can only be realized in community, that the individual is, by virtue of his solitude, an incomplete image and therefore an incomplete person. ${ }^{88}$ When God decided that it was not good for the man to be alone, He did not indicate that one reason for this was that His image in man was imperfect on that account. However important human community may be, it cannot be said that it is inherent in the image which, if anything, is designed to establish a relationship of community or fellowship primarily between man and God, not between male and female or between man and the lower creation. The relationship between Adam and Eve, and that between men and the rest of creation is specified in connection with the image, but as a consequence and not as an essential part of it.

The question of sin and the Fall of man, traditionally associated with the image, must now be resolved in a different way, not because of an evolutionary belief in man's development which excludes the possibility of $\sin ,{ }^{89}$ but because Scripture does not support a linking of these concepts with the doctrine of the image. The best way to do this is to think of the image as something given and immutable, an

\footnotetext{
${ }^{87}$ On this, see E. Hill, op. cit., 204-5, who demonstrates the absurdities which can result.

${ }^{88}$ K. Barth, Church Dogmatics III, 1 (Edinburgh 1958) 195-206, followed by C. Westermann, op. cit., 160.

${ }^{89}$ See W. Pannenberg, op. cit., 57 for a pro-evolutionary stance and P.E. Hughes, op. cit., 90-101 for the contrary view.
} 
ontological reality in the human being. ${ }^{90}$ When man sinned, his relationship with God was altered from one of obedience to one of disobedience, but there was no ontological change in man himself. ${ }^{91}$ Fallen man still has a relationship to God, who continues to speak to him and to demand obedience. Man in fact, is now guilty - something which would not be possible if the image were corrupted, lost or destroyed. Man has no excuse for this situation (Rom. 1:20). If the image were gone, man would not merely behave like an animal, but would actually be an animal, and therefore hardly responsible for his behaviour. The presence of the image is the presence of responsibility, which is at once the glory and the tragedy of fallen Adam.

In the light of this, it is impossible to accept the notion that evil is an anti-personal, or a depersonalising force. There is not the space to develop this idea fully here, but the continuing presence of the image of God in man, despite his sinfulness, must surely argue against a moral concept of personhood which would make such a doctrine plausible. We may also say in this connection that the postlapsarian image may be adduced in support of the notion of a personal Devil, though the case for that clearly has to be argued on other grounds as well. ${ }^{92}$

In conclusion we see that the real importance of man's creation in the image and likeness of God is that, unlike the rest of creation, human life is not an end in itself. A dog or a rose may come into existence and complete its life-cycle without engaging with its Creator. The dog may do any number of things which, if they were done by a human, would constitute a sin, and even a crime. Man is different. To him alone is given the privilege of fulfilling his earthly existence in relation to God, and this entails responsibility for his actions. The sort of ignorance which would be present if the image were removed is no excuse; there is no salvation by mitigation! In God's image is

\footnotetext{
${ }^{90}$ Against Westermann, who argues that the image is something dynamic, op. cit., 157. For a refutation of this, see G. Wenham, op. cit., 31.

${ }^{91}$ P.E. Hughes sees this clearly, op. cit., 168.

${ }^{92}$ On this important question see J.B. Russell, The Devil: Perceptions of Evil from Antiquity to Primitive Christianity, (Ithaca 1977) idem., Satan: The Early Christian Tradition, (Ithaca 1981) idem., Lucifer: The Devil in the Middle Ages, (Ithaca 1984) idem., Mephistopheles: The Devil in the Modern World, (Ithaca 1986).
} 
BRAY: The Significance of God's Image in Man

found man's primaeval uniqueness as a creature, his historical tragedy in Adam and his eschatological hope of redemption in Christ. 